\title{
An analysis of correlation between oceanographic parameters and productivity of trammel net in Prigi, Trenggalek
}

\author{
Sea Fadlina Hidayatus Syifa,*, Rizqi Abdi Perdanawati, Fajar Setiawan \\ Marine Science Department, Faculty of Science and Technology, UIN Sunan Ampel Surabaya, Indonesia \\ *E-mail: seasyifa8@gmail.com
}

\begin{abstract}
Prigi, Trenggalek is a potential fishery area located in the southern part of the East Java. Most fishers in Prigi uses trammel net as a capture device. The purpose of this research is to analyze the correlation of oceanographic parameters on the production of trammel net in Prigi's fishing ground. The data used in this research are temperature, $\mathrm{pH}$, salinity, velocity of currents, depth, and trammel net production during 35 trips. Oceanographic parameters in the fishing ground are temperature ranges from $26^{\circ} \mathrm{C}-31^{\circ} \mathrm{C}, \mathrm{pH}$ ranges from $7-9$, salinity ranges from $25 \%$ - $35 \%$, current velocity range $0.13 \mathrm{~m} / \mathrm{s}-0.39 \mathrm{~m} / \mathrm{s}$, and the water depth ranges from $10-18 \mathrm{~m}$. Variability from trammel net production are long tongue sole (Cynoglossus sp), crab (Portunus sp), endeavour shrimp (Metapenaeus sp), sea snail (Bufonaria sp), common ponyfish (Leiognathus sp), japanese threadfin bream (Nemipterus sp), squid (Loligo sp), and giant tiger prawn (Penaeus $\mathrm{sp})$ with total production $302.2 \mathrm{~kg}$. Correlation between oceanographic parameters and trammel net production are high for the current velocity with correlation value 0.78 , and medium for depth and temperature with correlation value are 0.56 and 0.45 , respectively. Correlation between salinity and $\mathrm{pH}$ with trammel net production are low and very low with correlation value -0.23 and 0.002 , respectively.
\end{abstract}

Keywords: oceanographic parameter, fisheries productivity, trammel net, correlation analysis.

\section{INTRODUCTION}

Trenggalek Regency, especially Prigi Waters is a potential fishing ground located in the Southern Waters of East Java. Prigi Waters is directly adjacent to the Indian Ocean [1]. Trammel net is a polyamide monofilamentbased net whose construction consists of three layers of net. The outer net has a mesh eye and a larger thread number compared to the inner net. The inner pocket has a net eye size and a smaller thread number than the outer layer net with the aim of trapping smaller marine biota [2].

The main catch target of trammel net in Prigi Waters is shrimp. Shrimp response to changes in environmental conditions causes shrimp resources to be distributed limitedly in marine waters. The condition can be an indication of the availability of shrimp at the fishing ground so that it can affect the production results [3]. Optimization from the use of trammel net is influenced by the direction of shrimp swimming motion, it is influenced by passive net system. The passive system of the trammel net causes the need for a location that has the availability of shrimp which is the main purpose of catching, where the availability of shrimp in an aquatic area is determined by oceanographic parameters in those waters [4].

Growth and development of shrimp in aquatic areas is generally influenced by oceanographic parameters. The influential oceanographic parameters are temperature, $\mathrm{pH}$, salinity, current speed, and water depth. Among these oceanographic factors, temperature is the most influential factor on the growth of marine organisms including shrimp [5]. The purpose of this study is to giving information about the composition of species and variability of trammel net catches operated in Prigi's fishing ground, and to analyze the influence of oceanographic parameters on trammel net productivity.

\section{METHODS}

Sampling Methods

The sampling method uses random methods by following fisher who are catching fish and then the researchers take the required oceanographic parameter data. Location determination based on the purpose of the research, is expected to represent the Prigi's fishing ground, Trenggalek regency. The research position that is the place of release of the net is then adjusted to the GPS (Global Positioning System).

\section{Calculation of Fisheries Productivity}

The calculation from composition of production results is carried out by considering the catch of each trip using scale platform. The weighing results obtained during 35 trips are then processed using Microsoft Excel 2010 to find out the composition of the production results. The composition of the production during the 35 fishing trips is calculated based on the relative abundance of each type of fish obtained. The composition of the type of fish produced can be known from the Equation (1) [6].

Fish $i$ Productivity $(\%)=\frac{n i}{N} \times 100$ 
where $i$ is a type of fish caught, $n i$ is the catch $(\mathrm{kg})$ of type of fish $i$, and $N$ is the total catch $(\mathrm{kg})$.

\section{Frequency of Catches Occurrences}

The frequency of occurrences is shown in percent. The frequency of occurrence data will be presented in the form of tables and bar graphs. This frequency of appearance data will show the probability of catching each type of fish in 35 fishing trips [6].

\section{Correlation Test}

Correlation test analysis is an analysis used to determine the relationship of oceanographic parameters of the water for the catch of trammel net. Correlation level analysis or relationship analysis between oceanographic parameters and net trammel catch using Pearson correlation analysis [7]. The Equations (2) are used to determine the correlation value based on Pearson Product Moment.

$r_{x y}=\frac{N \Sigma \mathrm{XY}-(\mathrm{X})(\mathrm{Y})}{\sqrt{N \Sigma X^{2}-\Sigma X^{2} N \Sigma Y^{2}-\Sigma Y^{2}}}$

where $r_{x y}$ is correlation coefficient, $N$ is number of samples, $\Sigma X$ is overall score for variable question items, $X \Sigma Y$ is overall score for question item variable $Y$.

The relationship level in this analysis is expressed in the correlation index value (0-1), while the correlation index value (Table-1) is the reference value for interpreting the level of relationship between the catch and the oceanographic parameter [8].

Table-1. Correlation interval and relationship level between factors

\begin{tabular}{|c|l|}
\hline Coefficient Interval & \multicolumn{1}{|c|}{ Relationship Level } \\
\hline $0.00-0.199$ & Very Low \\
\hline $0.20-0.399$ & Low \\
\hline $0.40-0.599$ & Medium \\
\hline $0.60-0.799$ & High \\
\hline $0.80-1.00$ & Very High \\
\hline
\end{tabular}

\section{RESULTS AND DISCUSSIONS \\ Research Site}

This research was conducted from April to July 2019 in Prigi waters, accurately in Tasikmadu Village, Watulimo District, Trenggalek, East Java (Figure-1). Prigi Waters Area stretches between $111^{\circ} 0^{\prime} \mathrm{BT}-114^{\circ} 4^{\prime} \mathrm{BT}$ and $7^{\circ} 12^{\prime} \mathrm{LS}-8^{\circ} 48^{\prime} \mathrm{LS}$, with an ocean area of $110,764.28$ $\mathrm{km}^{2}$.

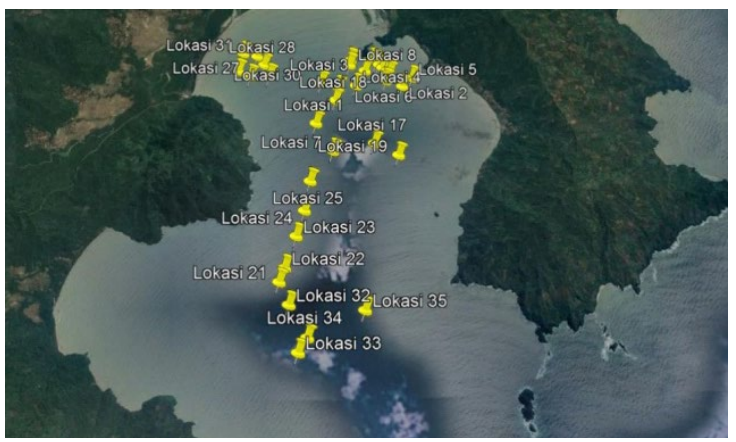

Figure-1. Research site
Fishing ground for fishers in the Prigi Waters area is the Indian Ocean WPP 573, with a wide range of fishing areas is expected to increase the number of fishing catches and can improve skills and knowledge that support fishery activities in the Prigi Waters area. Prigi Water Area has a sandy mud substrate and slightly rocky coral with a depth of about $15-61$ meters [1].

Trammel net fishers in the Prigi Waters region operate their net only within the bay area. The main types of catches of fishers using trammel net are endeavour shrimp (Metapenaeus affinis), giant tiger prawn (Penaeus monodon), and long tongue sole (Cynoglossus lingua). Fishers catch in Prigi Waters area is strongly influenced by environmental and surrounding conditions [1].

\section{Trammel Net Construction}

Trammel net or the term used by Prigi fishers is shrimp net that have a construction consisting of net bodies, buoys, ballast, and ropes (Figure-2). The body of the net is one of the main parts of the net that has the function to catch fish either by entering or entangled in the net. The body of the net is rectangular tied to the net top rope as well as the net bottom rope. The body of the net consists of three layers, namely one layer of inner net and two layers of outer mesh side the inner mesh layer. The size of the mesh eye on the inner layer ranges from $1.5-$ 1.75 inches $(38.1-44.4 \mathrm{~mm})$. The net eye on the outer layer is $3-4$ inches $(76.2 \mathrm{~mm}-101.6 \mathrm{~mm})$. A set of net has a length of about $75 \mathrm{~m}$ and a width of about $1.5 \mathrm{~m}$.

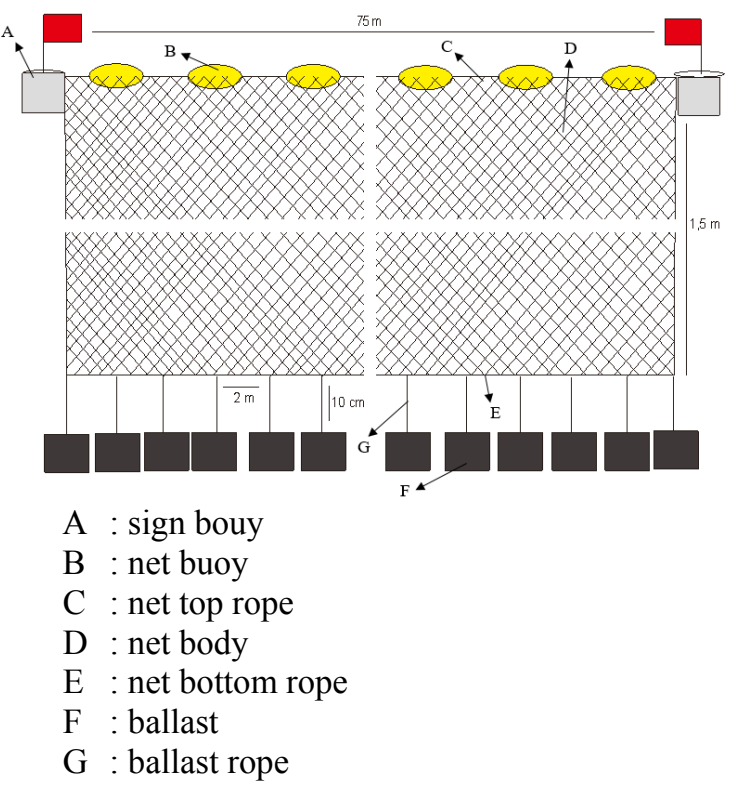

Figure-2. Trammel net construction

Buoy is one of the important components in the operation of trammel net. Buoys on trammel net consist of sign buoy and net buoy. Ballast on the trammel net has a function to give the force of drowning to the net, in addition the ballast also serves to restore or maintain the net at its original position due to the influence of water currents. Ballast net used by shrimp fishers in Prigi Waters are usually tin or cement formed tubes or cubes. Ballast net usually weigh about $360-400$ grams. Installation of ballast on a set of net that is $3 \mathrm{~m}$ away, the number of 
ballast on a set of net as much as 37 pieces with an installation distance of 2 meters.

The rope on the trammel net consists of buoy rope, net rope, and dive rope. The buoy rope of the trammel net is used to connect between the net buoy. Trammel net has two net rope, namely the net top rope and the net bottom rope. The net top rope becomes one with a buoy rope, the length of the net top rope corresponds to the length of a set of net on 75 meters. The net bottom rope on the trammel net layers into one with a mesh ballast rope. The length of the net bottom rope is $75 \mathrm{~m}$ and the diameter of the rope is $0.25 \mathrm{~cm}$, while the ballast rope is $10 \mathrm{~cm}$ long. The dive rope used on the trammel net is two pieces, namely the dive rope that is connected to the buoy sign of each end of the net. The one and two diver's ropes are fused with an uncertain length of the net top rope hanging over the water used as a fishing spot.

\section{Catches Variability}

The number and type of catches obtained by trammel net fishers during 35 fishing trips as much as eight types of fish are shown in Table-2. Based on Table-2 species with the highest number of catches is long tongue sole as much as $94.6 \mathrm{~kg}$, while the lowest catch is giant tiger prawn with a total catch of $17.3 \mathrm{~kg}$. The results of trammel net production for 35 trips are shown in Figure-3. The highest endeavour shrimp catch was on the fourth week with a catch count of $20 \mathrm{~kg}$, while the lowest number of catches was in the first week with the number of catches of $1.1 \mathrm{~kg}$ (Figure-3).

Table-2. Number and type of catches during 35 trips

\begin{tabular}{|l|l|c|c|}
\hline \multicolumn{1}{|c|}{ Spesies } & \multicolumn{1}{|c|}{$\begin{array}{c}\text { Common } \\
\text { Name }\end{array}$} & $\begin{array}{c}\text { Catches } \\
\text { (kg) }\end{array}$ & (\%) \\
\hline $\begin{array}{l}\text { Metapenaeus } \\
\text { sp. }\end{array}$ & $\begin{array}{l}\text { Endeavour } \\
\text { shrimp }\end{array}$ & 37.1 & 12 \\
\hline Penaeus sp. & $\begin{array}{l}\text { Giant tiger } \\
\text { prawn }\end{array}$ & 17.3 & 6 \\
\hline Portunus sp. & Crab & 56.5 & 19 \\
\hline Bufonaria sp. & Sea snail & 30.7 & 10 \\
\hline $\begin{array}{l}\text { Cynoglossus } \\
\text { sp. }\end{array}$ & $\begin{array}{l}\text { Long tongue } \\
\text { sole }\end{array}$ & 94.6 & 31 \\
\hline $\begin{array}{l}\text { Leiognathus } \\
\text { sp. }\end{array}$ & $\begin{array}{l}\text { Common } \\
\text { ponyfish }\end{array}$ & 26.8 & 9 \\
\hline Loligo sp. & Squid & 18.3 & 6 \\
\hline $\begin{array}{l}\text { Nemipterus } \\
\text { sp. }\end{array}$ & $\begin{array}{l}\text { Japanese } \\
\text { threadfin bream }\end{array}$ & 20.9 & 7 \\
\hline
\end{tabular}

Giant tiger prawn is the main catch target of trammel net because it has a high economic value. The highest number of catches by giant tiger prawn was on the fourth week with a catch of $7 \mathrm{~kg}$. The giant tiger prawn's lowest catch was in the second week with a catch of 1.4 $\mathrm{kg}$. Crab is one of the catches that always appears in 35 catching trips or always entangled in the net. The highest number of crab catches was in the fifth week with a catch of $21.2 \mathrm{~kg}$, while the lowest catch was in the first week with a total catch of $4.1 \mathrm{~kg}$ (Figure-3).

The highest number of sea snail production was on the fourth week with the amount of $13.5 \mathrm{~kg}$, while the lowest production result was in the third week with the number of catches of $0.6 \mathrm{~kg}$. Long tongue sole are the species with the highest number of catches delivered by other species. The highest number of long tongue sole catches was on the fourth week with a catch of $33.4 \mathrm{~kg}$, while the lowest catch was in the second week with the number of catches of $6.2 \mathrm{~kg}$ (Figure-3).

The highest number of common ponyfish catches was on the fourth week with a catch of $9.3 \mathrm{~kg}$. The lowest amount of production is in the first week with the number of catches of $3.8 \mathrm{~kg}$. Squid is a species that is not a target trammel net but is a catch species that has a high economic value. The highest number of squid catches was in the fifth week of $8.7 \mathrm{~kg}$, while the lowest catch was in the second week or no squid caught. Japanese threadfin bream production was the highest in the fifth week with a total production of $8.9 \mathrm{~kg}$, while the lowest production was in the second week with the amount of $0.9 \mathrm{~kg}$ (Figure-3).

Long tongue sole and crabs are the catches with the highest percentage of appearances of $100 \%$ or caught for 35 trips. Squid is the catch with the lowest percentage of appearances of $29 \%$ or caught 10 times in 35 trips (Table-3). Based on the composition of the type of net trammel catch during the 35 arrest trips showed that long tongue sole and crabs were dominantly caught compared to other types. The variability of trammel net catches operated in Prigi Waters showed the dominance of long tongue sole with total production of $94.6 \mathrm{~kg}$ during 35 capture trips or with a percentage of $31 \%$ (Table-3).

Based on total catches of trammel net during 35 fishing trips showed that long tongue sole and crabs were dominantly caught compared to other types. This may be determined by environmental and other factors around fishing ground. The percentage of the composition of trammel net production are shown in Figure-4. The crab production is a fairly high production of $56.5 \mathrm{~kg}$ or with a percentage of $19 \%$ (Figure-4). Endeavour shrimp and sea snail production during 35 capture trips has a number on a scale of $30-40 \mathrm{~kg}$ or a percentage of $10 \%-15 \%$, the total amount has a value close to each other (Figure-4). The amount of endeavour shrimp and sea snail production is almost the same as the frequency of its appearance. The percentage of endeavour shrimp appearance is higher than sea snails which is $89 \%$ or 31 times caught in 35 arrest trips, while the percentage of sea snail appearance is lower by $43 \%$ or 15 times caught during 35 arrest trips (Table-3).

Table-3. Frequency of fish species appearance during 35 fishing trips

\begin{tabular}{|l|c|c|c|}
\hline \multicolumn{1}{|c|}{$\begin{array}{c}\text { Common } \\
\text { Name }\end{array}$} & $\begin{array}{c}\text { Frequency of } \\
\text { Occurrences }\end{array}$ & $\begin{array}{c}\text { Relative } \\
\text { Frequency }\end{array}$ & $\mathbf{( \% )}$ \\
\hline $\begin{array}{l}\text { Endeavour } \\
\text { shrimp }\end{array}$ & 31 & 0.886 & 89 \\
\hline $\begin{array}{l}\text { Giant tiger } \\
\text { prawn }\end{array}$ & 24 & 0.686 & 69 \\
\hline Crab & 15 & 1.000 & 100 \\
\hline Sea snail & 35 & 1.000 & 100 \\
\hline $\begin{array}{l}\text { Long tongue } \\
\text { sole }\end{array}$ & 19 & 0.543 & 54 \\
\hline $\begin{array}{l}\text { Common } \\
\text { ponyfish }\end{array}$ & 10 & 0.286 & 29 \\
\hline Squid & 15 & 0.429 & 43 \\
\hline $\begin{array}{l}\text { Japanese } \\
\text { threadfin bream }\end{array}$ & & & \\
\hline
\end{tabular}




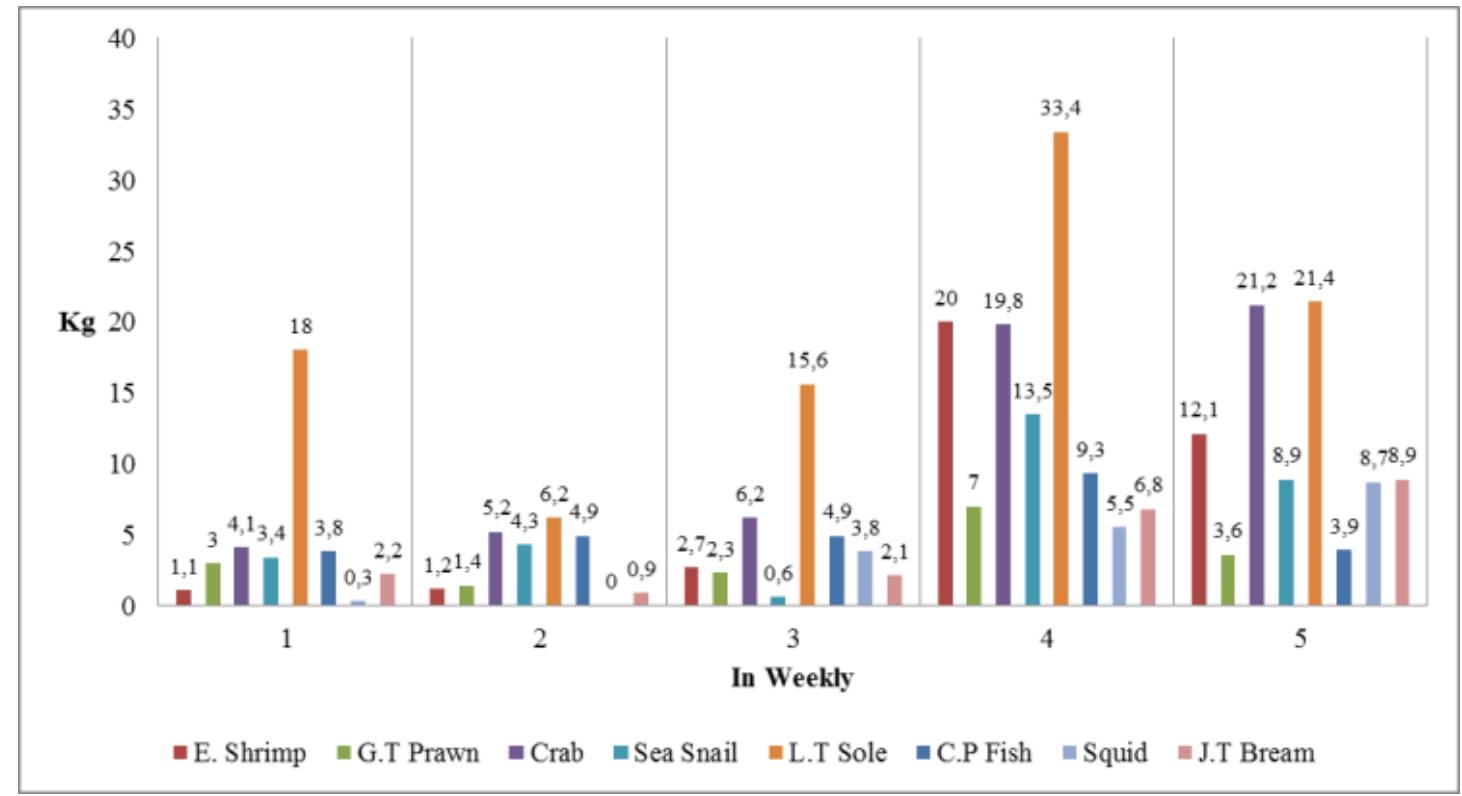

Figure-3. Chart of trammel net fish production in 35 fishing trips (5 weeks) in Prigi Waters

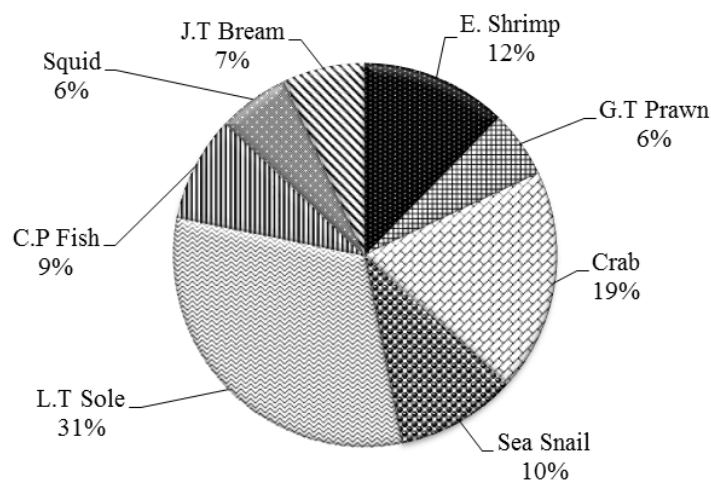

Figure-4. Composition of fish species based on total production during 35 net trammel capture trips

The percentage of common ponyfish and japanese threadfin bream catches is on a scale of $5 \%$ $10 \%$ or weighing $20-30 \mathrm{~kg}$ (Figure-4). The frequency of common ponyfish and japanese threadfin bream appearances is also relatively close, namely common ponyfish appeared 19 times during 35 arrest trips while japanese threadfin bream appeared 15 times during 35 arrest trips (Table-3). The percentage of production of giant tiger prawn and squid catches is equal to $6 \%$, but the frequency of squid appearance is only 10 times in 35 capture trips (Figure-4). This is in contrast to the Giant Tiger Prawn which has a percentage of appearance frequency of $69 \%$ or 24 times during 35 arrest trips. The percentage illustrates that the frequency of the appearance of giant tiger prawn is higher than squid even with the same percentage of production (Table-3).

\section{Oceanographic Conditions of Prigi Waters Temperature}

Temperature measurements at 35 points showed an average of $27.9{ }^{\circ} \mathrm{C}$, with a high of $31^{\circ} \mathrm{C}$ and a low of $26^{\circ} \mathrm{C}$. The results of different temperature measurements at 35 points are caused by differences in location and difference in measurement time (Figure-5). Differences in temperature range between arrest points can be influenced by differences in the location of the fishing point and the difference in the time of net withdrawal (hauling) [9].

The quality standard determination for trammel net catches is that the optimal temperature for the catching of trammel net ranges from $26^{\circ} \mathrm{C}-32^{\circ} \mathrm{C}$ [10]. This indicates that the temperature conditions in Prigi Waters are still attainable to be used as a fishing location using trammel net.

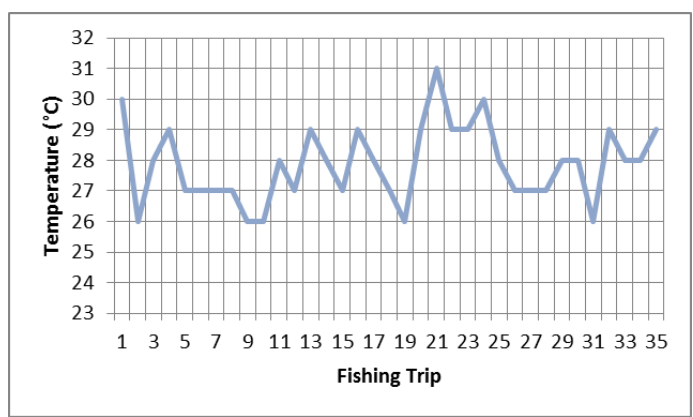

Figure-5. Sea surface temperature distribution

pH

$\mathrm{pH}$ is one of the oceanographic parameters that can affect the production of trammel net. Net yield will be optimal if the $\mathrm{pH}$ condition of the catching site is in optimal condition [10]. $\mathrm{pH}$ at each catching site in Prigi Waters ranges from 7 to 9 (Figure-6).

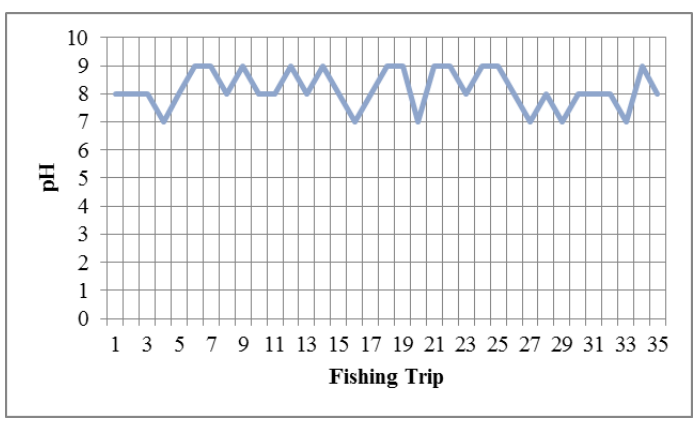

Figure-6. $\mathrm{pH}$ distribution 
The optimal $\mathrm{pH}$ for marine biota ranges from 7 to 8.5. Based on the measurements that have been done at 35 points of the catching locations using trammel net shows that the $\mathrm{pH}$ conditions are in conditions that are still feasible to be used for net trammel catching locations because it is still within the tolerance limit of $\mathrm{pH}$ levels for the waters [11].

\section{Salinity}

Salinity is one of the oceanographic parameters that affect the catch of the trammel net. Salinity distribution patterns in the waters are usually influenced by factors such as the influence of river flows around the water, rainfall, evaporation, and water circulation patterns [12]. Changes in salinity distribution patterns during 35 fishing trips in prigi waters ranged from $25 \%$ o to $35 \%$ o (Figure-7). Meanwhile, the optimal levels of salinity in an optimal water for marine biota range from $15 \%$ o to $30 \%$ [12].

Salinity levels at some point of capture, namely on the 1st trip is the point where the highest salinity value with a value of $35 \%$, at the point of the 5 th trip is the point with the second highest salinity value with a value of $34 \%$ (Figure-7). High salinity levels at these two points can be affected due to differences in water circulation patterns at each point of catching. Each location has basically a different basic shape allowing different current patterns to affect salinity levels in each capture location.

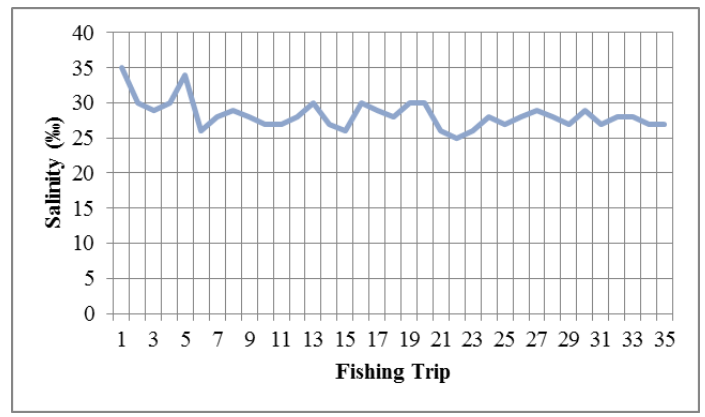

Figure-7. Salinity distribution

\section{Current Velocity}

Changes in current velocity distribution patterns in the Prigi Waters area during 35 trips with 35 points of the catching locations showed fluctuating patterns. The average current velocity for 35 trips is $0.23 \mathrm{~m} / \mathrm{s}$. The lowest current velocity for 35 trips is $0.13 \mathrm{~m} / \mathrm{s}$, while the top current velocity is $0.39 \mathrm{~m} / \mathrm{s}$ (Figure-8). Fluctuating current velocity distribution patterns can be affected by wind velocity and unstable weather.

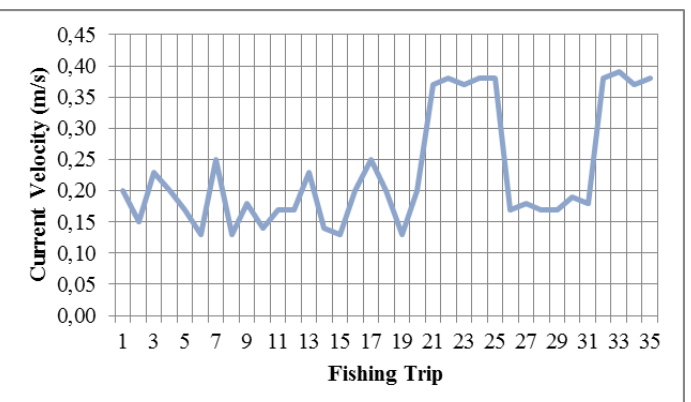

Figure-8. Current velocity distribution at trammel net research site
The velocity of currents in a water is closely related to the climate in these waters. In addition, the wind also greatly affects current velocity conditions in Prigi Waters because Prigi Waters are bays [13]. In the bay area, currents are strongly influenced by wind because the current is generated by the friction force between the wind and the water level [14].

\section{Water Depth}

Changes in water depth during 35 fishing trips are in the range of 10-18 $\mathrm{m}$ with an average water depth of $13.7 \mathrm{~m}$ (Figure-9). The depth of the capture site greatly affects the catch of the trammel net because the deeper water allows for a more optimal catch than the low depth.

In addition to the more varied variety of catches, the release of net at a depth of more than 5 meters allows the net to be safer than large ships operating for 24 hours in the Prigi Waters area. The depth is very influential on the catch of trammel net operated at the bottom of the water because the deeper the capture location, the more varied and more optimal the catch will be because the seabed biota tends to have low mobility [15].

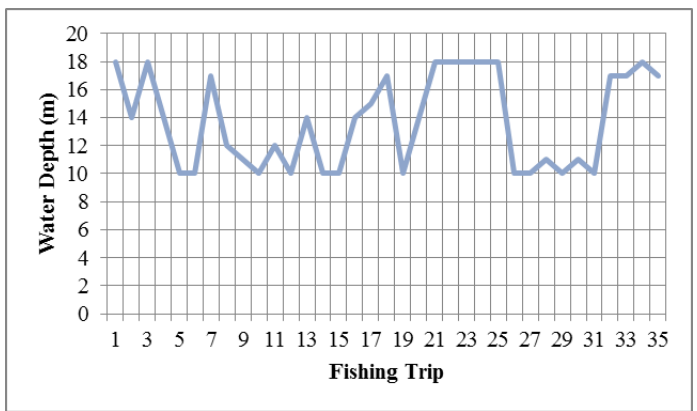

Figure-9. Water depth distribution

\section{Correlation of Oceanographic Parameters with Trammel Net Catches}

Based on measurement of oceanographic parameters of the waters of Prigi, Tasikmadu village, Watulimo district, Trenggalek Regency which will then be seen the level of correlation to the catch of trammel net. This correlation stage aims to look at the relationship between oceanographic parameters to trammel net catches.

The correlation testing stage is one of the testing stages used to determine the relationship between variables with each other. Conditions that must be satisfied to be able to be done correlation test is data obtained at the time of data retrieval in normal distributed conditions, as well as data obtained more than 30 sample data. Validation that the data received is distributed normally or not distributed normally is by conducting a normality test of the data received. Based on normality test, data are declared a normal distribution if it has P-Value value $>0.05$ while if the data has P-Value value of 0.05 then the data is declared not distributed normally [16].

Normality test results of data obtained on trammel net catches during 35 capture trips showed that the data obtained was distributed normally (P-Value $>0.05$ ) (Table-4). The results showed that a sample of data obtained during 35 trips could represent the actual conditions present at a research site. The data obtained as many as 35 samples were then used for correlation testing, in this case pearson correlation test was carried out. 
Table-4. Test normality of trammel net catches and oceanographic parameters data

\begin{tabular}{|l|c|}
\hline \multicolumn{1}{|c|}{ Parameters } & P-Value \\
\hline Trammel Net Catches & 0.163 \\
\hline Temperature & 0.180 \\
\hline $\mathrm{pH}$ & 0.253 \\
\hline Salinity & 0.189 \\
\hline Current Velocity & 0.256 \\
\hline Water Depth & 0.193 \\
\hline
\end{tabular}

Analysis of the relationship between parameters or correlation analysis between oceanographic parameters and trammel net catches using Pearson correlation analysis with XLSTAT software in Microsoft Excel 2010. The Pearson correlation index value between oceanographic parameters and the trammel net catch can be seen in Table-5.

Table-5. Pearson correlation index on trammel net catches and oceanographic parameters data

\begin{tabular}{|l|c|}
\hline \multicolumn{1}{|c|}{ Parameter } & Correlation \\
\hline Temperature & 0,45 \\
\hline $\mathrm{pH}$ & 0,002 \\
\hline Salinity & $-0,23$ \\
\hline Current Velocity & 0,78 \\
\hline Water Depth & 0,56 \\
\hline
\end{tabular}

Value + : direct correlation

Value - : opposite correlation

Product moment pearson correlation test between oceanographic parameters and net trammel catch for 35 trips with 35 point capture location has positive value $(+)$ or same correlation direction (unidirectional) at temperature, $\mathrm{pH}$, current velocity, and water depth, while in salinity parameters show negative value (-) or have opposite correlation direction (Table-5). The correlation value with a positive description $(+)$ will show a direct relationship between the value of aquatic oceanographic parameters and the number of trammel net catches. This means that the greater the value of oceanographic parameters of the water, the greater the number of trammel net catches. Different if the correlation index value shows a negative description (-) then it means the relationship between the value of oceanographic parameters of the water and the catch is inversely proportional. This means that the greater the value of oceanographic parameters of the waters, the smaller the number of trammel net catches, and instead if the smaller the value of oceanographic parameters, the greater the number of net catches [17].

The temperature has a moderate level of association with the trammel net catch with a correlation value of 0.45 (Table-5). The nature of the correlation between temperature and the catch of trammel net is positive $(+)$ which means, the higher the temperature value of the point of capture, the higher the catch obtained by trammel net fishers. High gillnet catches tend to be in a relatively high temperature water [9].
The $\mathrm{pH}$ oceanographic parameter has a level of association with the catch trammel net with a value of 0.002 (Table-5). This indicates that the $\mathrm{pH}$ has a very low effect on the catch trammel net at 35 arrest points. $\mathrm{pH}$ tends not to affect the catch of trammel net because the $\mathrm{pH}$ of the waters in general is of a fixed value or close to its value if it is still in the same area of water [10].

Salinity is one of the oceanographic parameters that have a degree of association with the catch of the trammel net with a low value and has a correlation value opposite to the value of -0.23 (Table-5). Correlation coefficient indicates that the number of catches trammel net has a low correlation and is opposite (negative), if the salinity value is lower then the catch is high and vice versa, while others are caused by other factors that are likely not to be research variables. It showed that salinity did not greatly affect the catch trammel net during 35 trips at 35 points.

The result of correlation calculations that indicate that salinity only shows low coefficient values and correlates opposite does not mean salinity does not affect trammel net catches, but it is likely that only a few species whose number of catches are affected by salinity. Light, salinity, and the availability of nutrients in a water greatly influence the presence of marine biota in a water [12].

Current velocity is one of the oceanographic parameters that have the highest positive correlation value with the catch of trammel net with a value of 0.78 (Table 5). This means there is a strong connection between the difference in the current velocity of an arrest site to the catch of the trammel net. The character of the correlation relationship between current velocity and trammel net catch is positive $(+)$ which means, the lower the current velocity of water will be followed by the lower the value of the catch, and the more if the velocity of the current of water where the catch will also increase.

The current velocity of water greatly affects the number of catchments of trammel net because the velocity of the current tends to affect the motion of the net. More free-moving nets will increase the potential for marine biota capture [10].

Water depth is an oceanographic parameter that has a moderate correlation value with a positive value $(+)$ related to the catch of trammel net. The result of correlation index between water depth and trammel net catch is 0.56 or correlation coefficient value is $56 \%$ or medium correlation (Table-5). Correlation coefficients showed that the number of net trammel net catches during 35 trips was influenced by water depth of $56 \%$, while others were caused by other factors used as research variables as well as those not used as research variables.

The character of the correlation between the water depth and the catch of trammel net is positive $(+)$, if the shallower the capture location, the lower the catch, and vice versa, if the depth of the capture location is deeper than the catch, will increase as well. The depth of water greatly affects the catch because it is basically getting deeper into water so the marine biota that lives on the seabed is more varied and tends to have a slow or less force of motion so as to allow the capture to be done more optimally [15]. 


\section{CONCLUSIONS}

Oceanographic parameters at 35 points of release of trammel net of Prigi waters are temperatures range from $26^{\circ} \mathrm{C}-31^{\circ} \mathrm{C}, \mathrm{pH}$ ranges from $7-9$, water salinity ranges from $25 \%$ - $35 \%$, current velocity range from $0.13 \mathrm{~m} / \mathrm{s}-$ $0.39 \mathrm{~m} / \mathrm{s}$, and water depths range from $10 \mathrm{~m}-18 \mathrm{~m}$. Variability and composition of trammel net production are long tongue sole (Cynoglossus sp) with a total of $31 \%$, crab (Portunus sp) with a total of $19 \%$, endeavour shrimp (Metapenaeus sp) with a total of $12 \%$, sea snail (Bufonaria $\mathrm{sp}$ ) with a total of $10 \%$, common ponyfish (Leiognathus $\mathrm{sp)}$ with a total of $9 \%$, japanese threadfin bream (Nemipterus sp) with a total of 7\%, squid (Loligo sp) with a total of $6 \%$, and giant tiger prawn (Penaeus sp) with a total of $6 \%$ of the total production of $302.2 \mathrm{~kg}$.

The results of analysis show that current velocity has the highest correlation index value to a value of 0.78 or a strong correlation. The depth of the water has a moderate correlation value with a value of 0.56 . Temperature has a moderate level of relationship with a correlation index of 0.45 . Salinity has a low level of relationship with a correlation index value of -0.23 . $\mathrm{pH}$ has the lowest correlation value of 0.002 or a very low correlation. Based on the correlation and the value of oceanographic parameters from 35 fishing points, it can be seen that the parameters of Prigi waters are very supportive as a fishing area using a trammel net. This is based on the fact that all the parameters used in this study meet the requirements of the established water quality standards.

\section{REFERENCES}

[1] Direktorat Jenderal Perikanan Tangkap. 2018. Profil Pelabuhan Perikanan Nusantara Prigi, Trenggalek. Kementerian Kelautan dan Perikanan. Indonesia.

[2] Fachrussyah, Z. C. 2016. Dasar-Dasar Penangkapan Ikan. Buku Ajar. Universitas Negeri Gorontalo. Gorontalo.

[3] Priadna, F., A. N. Bambang, dan F. Kurohman. 2017. Analisis Pendapatan Nelayan Jaring Gondrong (Trammel Net) di Desa Siklayu, Kabupaten Batang, Jawa Tengah. Jurnal Perikanan Tangkap: Indonesian Journal of Capture Fisheries. 1(1): 1-7.

[4] Ruga S. R., Febrianti, dan Susiana. 2018. Hasil Tangkapan Udang pada Alat Tangkapan Bagan Tancap Berdasarkan Faktor Oseanografi di Perairan Senggarang. Universitas Maritim Raja Ali Haji. Kepulauan Riau.

[5] Bakpas A. L. 2011. Variabilitas Hasil Tangkapan Jaring Insang Tetap Hubungannya dengan Kondisi Oseanografi di Perairan Kabupaten Kolaka Utara, Sulawesi Tenggara. Skripsi. Fakultas Ilmu Kelautan dan Perikanan, Universitas Hasanuddin. Makassar.

[6] Salim, G. dan Pius Bae. 2017. Analisis Identifikasi Komposisi Hasil Tangkapan Menggunakan Alat Tangkap Jaring Insang Hanyut (Drift Gill Net) di Sekitar Pulau Bunyu, Kalimantan Utara. Jurnal Hardopon Borneo.10(1): 13-22.

[7] Sugiyono. 2012. Metode Penelitian Kuantitatif Kualitatif dan R\&D. Alfabeta. Bandung.

[8] Sugiyono. 2005. Memahami Penelitian Kualitatif. Alfabeta. Bandung.
[9] Putra, F. A., Zahidah H., Noir, dan N.P. Purba. 2016. Kondisi Arus dan Suhu Permukaan Laut pada Musim Barat dan Kaitannya dengan Ikan Tuna Sirip Kuning (Thunnus albacares) di Perairan Selatan Jawa Barat. Jurnal Perikanan Kelautan. 7(1): 156163.

[10] Nugraha, A. 2018. Adaptasi Nelayan Trammel Net di Pelabuhan Perikanan Samudera Cilacap Terhadap Perubahan Musim. Skripsi. Fakultas Perikanan dan Ilmu Kelautan, Institut Pertanian Bogor. Bogor.

[11] Kementrian Lingkungan Hidup Republik Indonesia. 2004. Keputusan Menteri Lingkungan Hidup No.51 tentang Baku Mutu Air Laut. Jakarta.

[12] Djuwito, G. S. Pratiwi, dan S.W. Saputra. 2016. Kelimpahan Larva Udang Penaeid pada Ekosistem Mangrove di Desa Pasar Banggi, Kabupaten Rembang. Management of Aquatic Resources. 5(4): 412-419.

[13] Simatupang, C. M., S. Heron, dan A. Agus Salim. 2016. Analisis Data Arus di Perairan Muara Sungai Banyuasin Provinsi Sumatera Selatan. Maspari Journal. 8(1): 15-24.

[14] Raeny, W., Aida Sartimbul, dan Citra Satrya Utama Dewi. 2016. Analisis Arus Pasang Surut Teluk Prigi, Trenggalek Menggunakan Model Advance Circulation. Pertemuan Ilmiah Nasional Tahunan (PIT) XIII Ikatan Sarjana Oseanologi Indonesia (ISOI). November 2016.

[15] Apriliyanto, H., Pramonowibowo, dan T. Yuliyanto. 2014. Analisis Daerah Penangkapan Rajungan dengan Jaring Insang Dasar (Bottom Gillnet) di Perairan Betahlawang, Demak. Fisheries Resources Utilization Management and Technology. 3(3): 7179.

[16] Cahyono, T. 2015. Statistik Uji Normalitas. Yayasan Sanitarian Banyumas. Purwokerto.

[17] Sitorus, M. 2009. Hubungan Nilai Produktivitas Primer dengan Konsentrasi Klorofil-a, dan Faktor Fisik Kimia di Perairan Danau Toba, Balige, Sumatera Utara. Skripsi. Fakultas Biologi, Universitas Sumatera Utara. Medan. 